\title{
Myocardial Infarction Complicated with Ventricular Rupture and Pseudo-Aneurysm Formation
}

\author{
Elisabeta Himcinschi, Elena Beganu, Daniel Cernica \\ Center of Advanced Research in Multimodality Cardiac Imaging, Cardio Med Medical Center, Tîrgu Mureș, Romania
}

\section{CORRESPONDENCE}

Elena Beganu

Str. 22 Decembrie 1989 nr. 76

540124 Tîrgu Mureș, Romania

Tel: +40 265217333

E-mail: beganu.elena@yahoo.com

\section{ARTICLE HISTORY}

Received: July 24, 2017

Accepted: August 7, 2017
Elisabeta Himcinschi • Str. 22 Decembrie $1989 \mathrm{nr} .76$ 540124 Tîrgu Mureș, Romania. Tel: +40 265217333. E-mail: eli_himcinschi@yahoo.com

Daniel Cernica • Str. 22 Decembrie $1989 \mathrm{nr}$. 76, 540124 Tîrgu Mureș, Romania. Tel: +40 265217333. E-mail: daniel.cernica@gmail.com
A 66-year-old man presented at the emergency room with severe pain, dyspnea, dizziness, and a significant medical history for cardiovascular disease including multiple episodes of constrictive chest pain that started 3 weeks before admission, ischemic heart disease, three previous ischemic strokes, arterial hypertension, as well as prostate adenocarcinoma treated with radio- and chemotherapy.

The clinical examination revealed hypotension $(70 / 40 \mathrm{mmHg})$, tachycardia (134 beats per minute), and right body motor deficit; vesicular breath sounds with wet pulmonary crackles in the lower region of the pulmonary projections, bilaterally, and a systolic murmur in the mitral auscultation point.

The electrocardiogram was interpreted as sinus rhythm with a heart rate of 134 beats per minute, right bundle branch block, and $\mathrm{qS}$ waves with negative $\mathrm{T}$ waves in the inferior leads. The laboratory analyses showed mild anemia, hypertriglyceridemia, myocardial necrosis enzymes at the upper limit values - NT-proBNP $6,748 \mathrm{pg} / \mathrm{mL}, \mathrm{D}$-dimer $>5.00 \mu \mathrm{g} / \mathrm{mL}$. The echocardiographic examination found a systolic depressed function of the left ventricle with lateral wall hypokinesia, a pericardial collection with concentric distribution of $34 \mathrm{~mm}$, partial right atrium and $\mathrm{mid} /$ end-diastolic right ventricle collapse, a pseudoaneurysm of the posterior wall of the left ventricle with a thrombus of $50 \mathrm{~mm}$, as well as stage III ischemic mitral regurgitation (Panel A). The computed tomography angiography and cardiac computed tomography scan revealed the left ventricle pseudoaneurysm and thrombus mass (Panel B), as well as new findings such as a dissected aneurysm at the level of the ascending aorta $(82.4 \mathrm{~mm})$ with a circulating lumen of $45 \mathrm{~mm}$ (Panel C).

The patient was diagnosed with recurrent inferior myocardial infarction, recently complicated with a ruptured inferior-wall pseudoaneurysm of the left ventricle, hemorrhagic pericardial effusion, a hemodynamically significant ischemic mitral regurgitation, and aortic dissection.

In post-myocardial infarction patients, with complications such as left ventricular pseudoaneurysm, cardiovascular surgery recommendations include a delayed surgical correction that should follow a complete stabilization of the vital parameters of the patient and diagnostic coronary angiography. ${ }^{1,2}$ Noninvasive im- 

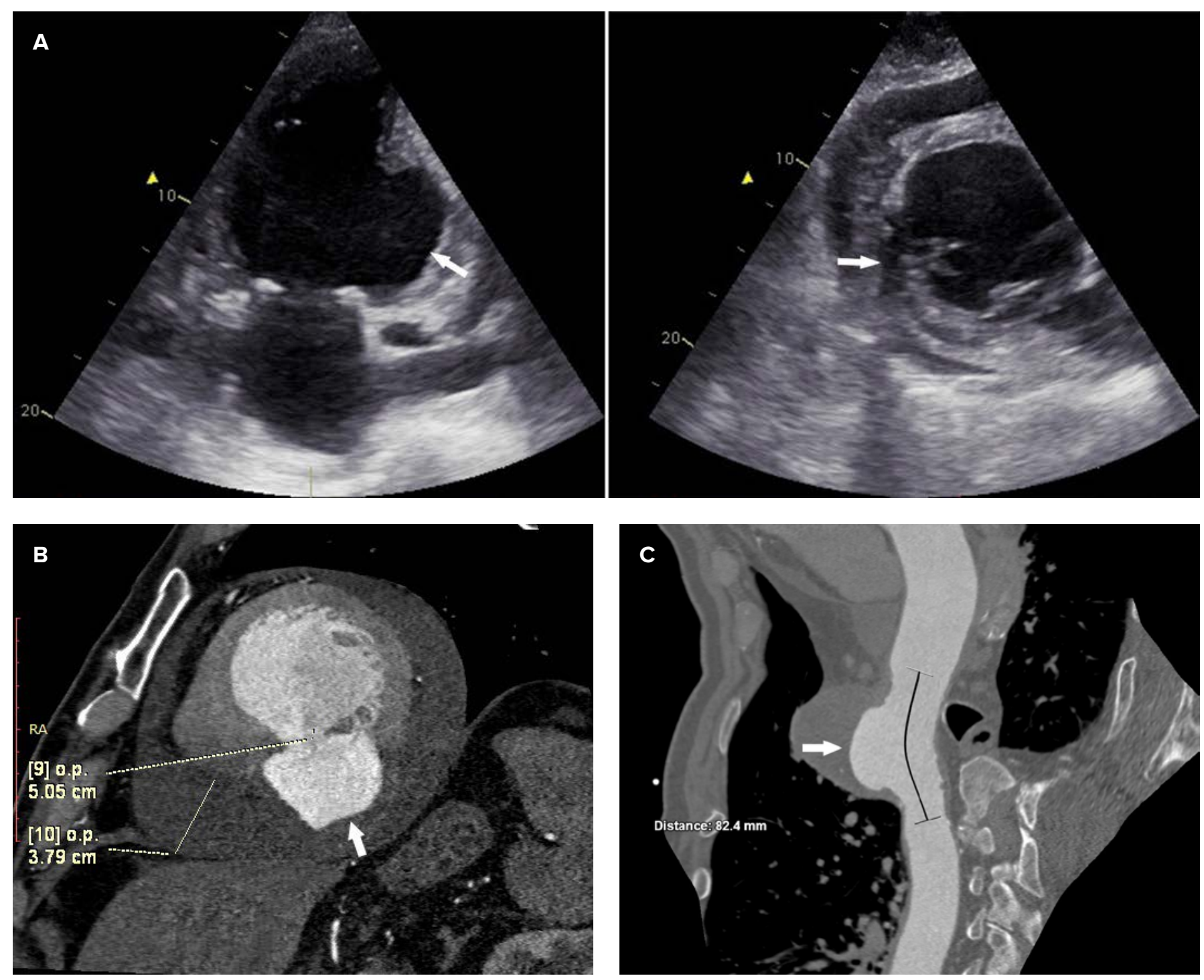

aging methods can be used for accurately diagnosing and assessing myocardial infarction complications, including transthoracic and transesophageal echocardiography and cardiac computed tomography. ${ }^{3}$ The rupture of a left ventricular pseudoaneurysm is a rare and fatal complication of myocardial infarction. ${ }^{4,5}$

The patient agreed to the publication of her data, and the institution where the patient had been admitted, approved the publication of the case.

\section{REFERENCES}

1. Prifti $\mathrm{E}$, Bonacchi M, Baboci A, et al. Surgical treatment of post-infarction left ventricular pseudoaneurysm: Case series highlighting various surgical strategies. Ann Med Surg (Lond). 2017;16:44-51.

2. Camm CF, Neubauer S, Taggart DP, Rider OJ. Ventricular Rupture Following Myocardial Infarction. J Invasive Cardiol. 2017:29:E60.

3. Yesin M, Kalçık M, Alizade E, Taşar O, Özkan M. Multimodality imaging of a left ventricular aneurysm in a patient with normal coronary arteries: Unusual localization. Echocardiography. 2017;34:1110-1111.

4. Meng X, Yang YK, Yang KQ, et al. Clinical characteristics and outcomes of left ventricular pseudoaneurysm: A retrospective study in a single-center of China. Medicine (Baltimore). 2017;96:e6793.

5. Chen SJ, Zhang C, Meng QT, Peng Y, Chen M. Sudden death due to ventricular double rupture as a complication of inferior acute myocardial infarction. Medicine (Baltimore). 2016;95:e5757.

\section{CONFLICT OF INTEREST}

Nothing to declare. 